\title{
An emergy evaluation of a medieval water management system: the case of the underground "Bottini" in Siena (Italy)
}

\author{
R. M. Pulselli, B. Rugani, E. Tiezzi \& N. Marchettini \\ Ecodynamics Group, Department of Chemistry, University of Siena, Italy
}

\begin{abstract}
In the middle ages, Siena had a high population density and had to face the problem of water supply within the city walls for housing, crafts, industrial activities and fire risks. With this aim, a series of underground drifts, namely "Bottini", was built at the beginning of the 13th century and achieved a total length of $25 \mathrm{~km}$ in the 14th century. Bottini have been capturing rain water and conducting it from the countryside to the fountains in the city centre for centuries. Brick pavements and other structures, such as brick vaults (where necessary), guaranteed water clearness and allowed a special team of workers, "bottinieri", to move throughout the tunnels for management and maintenance. Bottini still bring $9.5 \mathrm{l} / \mathrm{s}$ of clear water. Currently water is only used to fill the fountains and is then wasted. Based on statistics on water use, we argued that the activity of maintaining Bottini is not only a good practice for the conservation of a precious cultural heritage, but could also be potentially an opportunity for improving urban ecology. In this paper, we propose to investigate the environmental impact of water use comparing Bottini with a contemporary water management system. In particular, an "emergy evaluation" was developed for providing information about the sustainability of water use, both nowadays and in the past. Preliminary results showed that Bottini have a much lower environmental impact and can be potentially reused by withdrawing water and using it for some activities - such as irrigation of gardens and playgrounds, street washing and sanitary use - within the historical centre of Siena.
\end{abstract}

Keywords: cultural heritage, energy systems diagrams, water management. 


\section{Introduction}

The city of Siena was built upon three hills (about $350 \mathrm{~m}$ sea-level) and was an extremely dynamic centre during the middle ages, in particular, in the 13th and early 14 th centuries [1]. In 1328, the population achieved around 80,000 people [2], and Siena prospered with an economy mostly based on agriculture, services, such as banking and lodging, and industrial activities, mainly textiles, butchers, wool and leather [3]. The high population density and the emergence of new activities within the city walls caused an increasing demand of water for housing and industrial uses. An innovative water management system was thus built in order to bring water from the external countryside into the city and supply all the districts of the medieval city (1226-1460 a.C.) [2]. The geological composition under the surface of Siena, basically made of various layers of sedimentary materials (from fine sandstone to clay), allowed one to build an efficient underground aqueduct, namely the "Bottino" (due to the brick vaults built in some sections of the excavated tunnels) [4]. Made of a network of underground drifts with an average slope of $1-2 \%$, it achieved a total length of about $25 \mathrm{~km}$ in the late 14th century [2]. Bottini (plural of Bottino) have been capturing rain water, filtered through the ground, for centuries and conducting it to the fountains, namely "fonti" (plural of fonte), in the city centre. Fountains in Siena were built to be highly accessible and efficient, 24h/day, held in check by guardians and well managed and cleaned [2]. The main fountains had three collection pools, located at different levels: a) the highest, which received the water directly from the Bottino, used for drinking and cooking; b) the medium used by animals; c) the lowest used for washing clothes. Finally, the overflow was often used for crafts or industrial activities. The average section of the Bottino has a height of $1.8 \mathrm{~m}$ and a width of $0.8 \mathrm{~m}$ In the Bottino, brick pavements (with a sort of gutter, namely gorello, made of bricks and clay) and other structures, such as brick vaults (built where necessary), guaranteed water clearness and allowed a special team of workers, "bottinieri", to move throughout the tunnels for management and maintenance. In the present time, Bottini still provide an average of $9.5 \mathrm{l} / \mathrm{s}$ of clear water to the fountains, although it is not drinkable [6]. The main problems to their efficiency are due, firstly, to the calcification of galleries and floors that obstruct water outflow and, secondly, to the construction of buildings in the northern periphery of Siena, out of the ancient walls, that caused in recent years a decrease of rain water inflow to the underground.

Since Bottini are an amazing evidence of an ingenious work of architecture and engineering in the past, they are nowadays considered as cultural heritage. Moreover, they are an efficient system that still provides water to fountains within the historical centre of Siena. Nevertheless, once conveyed in the fountains, water is not used and is wasted. Based on statistics on water use [7], we therefore argue that the activity of maintaining Bottini might be not only a good practice for their conservation, but could also be potentially an opportunity for promoting a reuse of water and improving urban ecology. 

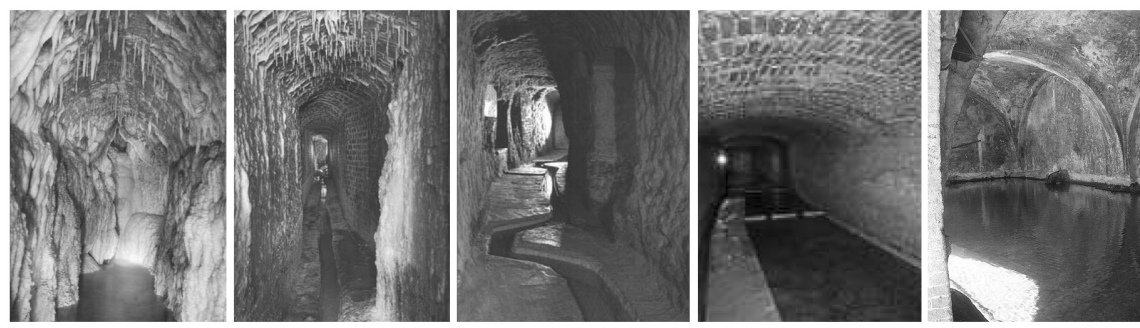

Figure 1: $\quad$ Images of the underground Bottini in Siena (Italy).

In this paper, we investigated the environmental efficiency of water use comparing the system of ancient Bottini with a contemporary water management system. In particular, an emergy evaluation (EE) (emergy spelled with an "m") was developed for providing information about sustainability of water use, both nowadays and in the past.

The following analysis focussed on the Bottino of Fonte Branda (built in 1195 a.C.), $6326 \mathrm{~m}$, excavated at an average depth of $17.5 \mathrm{~m}$. This brings to the fountain (Fonte Branda) an average quantity of water of $3.5 \mathrm{l} / \mathrm{s}$ [3].

\section{Method}

Emergy (spelled with an "m") is a measure of available energy that was used previously, directly and indirectly, to generate the inputs for an energy transformation [9]. Emergy means energy memory. The emergy evaluation uses the thermodynamic basis of all forms of energy and materials to convert them into equivalents of one form of energy, the solar energy [9]. Emergy is thus given in units of solar energy, namely solar emergy Joule or solar emjoule (seJ). In general emergy is a measure of natural resources that have been used throughout a sequence of processes towards a final product. Previously calculated coefficients (emergy per unit energy or mass) can be used to transform a specific product or service into emergy. These unit emergy values are used for multiplying mass quantities $(\mathrm{kg})$ or energy quantities (joule) and accounting for their emergy content.

Emergy values per unit are usually given in literature and represent the environmental resource use per unit mass or energy in a given process, such as human work, or product, such as bricks or mortar. Values usually refer to current procedures and systems. Since these values should be coherent to a specific production process or a reference system, a special accounting was performed here. In particular, unit emergy values of human work and materials were accounted taking into account procedures and environmental resource use in the age of the Siena Republic (XII-XVI century).

In the first case we inventoried the main inputs to the regional system including renewable resources, such as solar irradiation, rain, geothermal heat and soil erosion (the latter being renewable considering sustainable ecoagricultural systems), local non renewables (extracted materials) in a area of $8325 \mathrm{~km}^{2}$ with an average population of 70000 people. We obtained an emergy 
per person equal to $1.46 \times 10^{16} \mathrm{seJ} / \mathrm{yr}$ and thus a unit emergy value of $3.18 \times 10^{6}$ sej/J with a portion of renewability almost equal to $100 \%$. In the present year, the emergy per person was estimated at $1.24 \times 10^{7} \mathrm{sej} / \mathrm{J}$ (5\% rate of renewability) [9].

In the second case, considering the production process of bricks, inputs inventoried were: materials (clay and sand), energy (fired wood) and human work. The specific emergy of brick in the XII-XIV centuries was thus $2.39 \times 10^{9}$ sej/g, with a portion of renewables of $14 \%$. In the present time, specific emergy of bricks is $3.68 \times 10^{9} \mathrm{sej} / \mathrm{g}, 100 \%$ non renewable [9].

\section{Results and discussion}

The emergy analysis was performed considering the main energy and material inflows to the system Bottino Fonte Branda. This included:

1) the main renewable inflow that corresponds to an amount of rain water that falls within a hypothetical region along the course of the underground Bottino;

2) inputs to the construction process for building the Bottino performed 720 years ago. This includes materials such as brick and mortar for the floor and the vaults, and human work (estimated 2152 working hours/yr $\times 8$ workers $\times 5$ years);

3) inputs to the construction process for building la fonte, namely Fonte Branda, 720 years ago. This also includes materials and human work (estimated 2152 working hours $/ \mathrm{yr} \times 12$ workers $\times 1$ year);

4) human work needed for the management and maintenance of the Bottino from its construction to the end of the historical Republic of Siena (maintenance: 2152 working hours $/ \mathrm{yr} \times 2$ workers $\times 362$ years; management: 2152 working hours $/ \mathrm{yr}$ $\times 1$ worker $\times 362$ years); (note that human work for the management was not added);

5) human work (2152 working hours/yr $\times 2$ workers in the last 10 years) and energy (electricity use for lighting and machines) needed for the maintenance of the Bottino in the last 10 years until now.

The analysis is shown in table 1 . Columns in the table report the estimated quantity and units of inputs, operational time values (i.e. the amount of working hours in a give process), specific emergy values (transformation coefficients), total emergy (the correspondent emergy quantity of each input given in seJ), lifetime values (lifetime of a given structure), emergy per year values (estimated emergy flow, given in sej/yr, up to the present state).

About lifetime of structures such as pavements or vaults, this corresponds to a maximum of 720 years if a structure has persisted since its construction, or to a lower value if parts were progressively degraded and substituted within an estimated time.

Results show that, considering the total emergy memorized in the Bottino as it is at its present state, the emergy flow, namely empower, is equal to $1.52 \times 10^{18}$ seJ/yr. Almost $99 \%$ of this emergy flow comes from renewable inputs. The Environmental Loading Ratio, given by the ratio between non renewable resources (both local $\mathrm{N}$ and imported $\mathrm{F}$ ) and renewable is 0.1 , therefore extremely low. 
Table 1: Emergy evaluation of the Bottino Fonte Branda in Siena. The emergy value per unit water is given in the last row.

\begin{tabular}{|c|c|c|c|c|c|c|c|c|}
\hline Items & type of input & quantity & unit & $\begin{array}{c}\text { operational } \\
\text { time }\end{array}$ & $\begin{array}{l}\text { specific } \\
\text { emergy }\end{array}$ & total emergy & $\begin{array}{l}\text { life } \\
\text { time }\end{array}$ & $\begin{array}{c}\text { emergy per } \\
\text { year }\end{array}$ \\
\hline & & & & hours & sej/unit & sej & years & sej/yr \\
\hline \multicolumn{9}{|l|}{ Local resources } \\
\hline rain & $\mathrm{R}$ & $9.83 E+10$ & $\mathrm{~g} / \mathrm{yr}$ & & $1.45 \mathrm{E}+05$ & & & $1.42 \mathrm{E}+16$ \\
\hline \multicolumn{9}{|l|}{ Construction "bottino" } \\
\hline brick (floar) & $14 \% \mathrm{R}-86 \% \mathrm{~N}$ & $3.04 \mathrm{E}+08$ & $\mathrm{~g} / \mathrm{yr}$ & & $2.39 \mathrm{E}+09$ & $7.27 \mathrm{E}+17$ & 100 & $7.27 \mathrm{E}+15$ \\
\hline brick (structure) & $14 \% R-86 \% N$ & $2.47 \mathrm{E}+09$ & $\mathrm{~g} / \mathrm{yr}$ & & $2.39 \mathrm{E}+09$ & $5.91 \mathrm{E}+18$ & 720 & $8.21 \mathrm{E}+15$ \\
\hline mortar (20\%brick) & $14 \% \mathrm{R}-86 \% \mathrm{~N}$ & $4.94 \mathrm{E}+08$ & $\mathrm{~g} / \mathrm{yr}$ & & $2.39 E+09$ & $1.18 \mathrm{E}+18$ & 720 & $1.64 \mathrm{E}+15$ \\
\hline human work & $\mathrm{R}$ & $5.23 E+05$ & $\mathrm{~J} / \mathrm{h}$ & 86080 & $3.18 \mathrm{E}+06$ & $1.43 \mathrm{E}+17$ & & $1.43 E+17$ \\
\hline \multicolumn{9}{|l|}{ Construction "fonte" } \\
\hline brick (structure) & $14 \% R-86 \% N$ & $5.00 \mathrm{E}+08$ & $\mathrm{~g} / \mathrm{yr}$ & & $2.39 \mathrm{E}+09$ & $1.20 \mathrm{E}+18$ & 720 & $1.66 \mathrm{E}+15$ \\
\hline brick (floar) & $14 \% \mathrm{R}-86 \% \mathrm{~N}$ & $1.73 E+07$ & $\mathrm{~g} / \mathrm{yr}$ & & $2.39 \mathrm{E}+09$ & $4.14 \mathrm{E}+16$ & 100 & $4.14 \mathrm{E}+14$ \\
\hline mortar (20\%brick) & $14 \% \mathrm{R}-86 \% \mathrm{~N}$ & $1.00 \mathrm{E}+08$ & $\mathrm{~g} / \mathrm{yr}$ & & $2.39 \mathrm{E}+09$ & $2.39 \mathrm{E}+17$ & 720 & $3.32 \mathrm{E}+14$ \\
\hline gravel & $\mathrm{N}$ & $8.00 \mathrm{E}+07$ & $\mathrm{~g} / \mathrm{yr}$ & & $2.39 E+09$ & $1.91 \mathrm{E}+17$ & 720 & $2.66 \mathrm{E}+14$ \\
\hline human work & $\mathrm{R}$ & $5.23 E+05$ & $\mathrm{~J} / \mathrm{h}$ & 25824 & $3.18 \mathrm{E}+06$ & $4.30 \mathrm{E}+16$ & & $4.30 \mathrm{E}+16$ \\
\hline \multicolumn{9}{|c|}{ Past management and maintenance } \\
\hline human work (management) & $\mathrm{R}$ & $5.23 \mathrm{E}+05$ & $\mathrm{~J} / \mathrm{h}$ & 1558048 & $3.18 \mathrm{E}+06$ & $2.60 \mathrm{E}+18$ & & $2.60 \mathrm{E}+18$ \\
\hline human work (maintenance) & $\mathrm{R}$ & $5.23 E+05$ & $\mathrm{~J} / \mathrm{h}$ & 779024 & $3.18 \mathrm{E}+06$ & $1.30 \mathrm{E}+18$ & & $1.30 \mathrm{E}+18$ \\
\hline \multicolumn{9}{|l|}{ Maintenance } \\
\hline human work (bottinieri) & $5 \% R-95 \% F$ & $5.23 E+05$ & $\mathrm{~J} / \mathrm{h}$ & 43040 & $1.24 \mathrm{E}+07$ & $2.79 \mathrm{E}+17$ & & $6.49 \mathrm{E}+12$ \\
\hline \multirow[t]{2}{*}{ electricity } & $\mathrm{F}$ & $2.93 \mathrm{E}+07$ & $\mathrm{~J} / \mathrm{h}$ & 5061 & $2.07 \mathrm{E}+05$ & $6.05 \mathrm{E}+12$ & & $2.07 \mathrm{E}+05$ \\
\hline & & & & & & & & $1.52 \mathrm{E}+18$ \\
\hline \multicolumn{9}{|l|}{ Physical data } \\
\hline lenght of bottino & & 6326 & $\mathrm{~m}$ & & & & & \\
\hline water & & 3.50 & $1 / \mathrm{s}$ & & & & & \\
\hline annual water provided & & $1.10 \mathrm{E}+08$ & $1 / y r$ & & $1.38 \mathrm{E}+10$ & \multicolumn{3}{|c|}{$\begin{array}{l}\text { sej/l or sej/kg } \\
\text { EMERGY PER UNIT WATER }\end{array}$} \\
\hline
\end{tabular}

Moreover, the emergy per unit water brought into Fonte Branda by the Bottino is $1.38 \times 10^{10} \mathrm{seJ} / \mathrm{kg}$ and corresponds to an amount of resources used almost totally renewable.

This value can be compared with the corresponding value obtained for a litre of water provided nowadays by the modern water management system [9]. This corresponds to $3 \times 10^{9} \mathrm{seJ} / \mathrm{kg}$ with a renewable portion of $25 \%$. The ELR was 3 . The results clearly highlighted that the environmental impact of water in Fonte Branda, referring to the demand for environmental resources, is much lower than the impact of the modern system because completely renewable and sustainable.

\section{Conclusion}

Dealing with housing, in Italy about $1 \%$ of water use is for drinking and $16 \%$ is used in the kitchen, $39 \%$ is for bathroom and $20 \%$ for other sanitary uses, $12 \%$ is for laundry and $6 \%$ for car washing, $6 \%$ is for other uses. Based on statistical data we can argue that drinkable water is just a portion of around $20 \%$ of total water use. The ancient water management system in Siena, the underground Bottini, still provides an average of $9.5 \mathrm{l} / \mathrm{s}$ of non drinkable but clear water. This is currently used to fill the fountains and then wasted.

In the present time, the maintenance of the Bottini in Siena is due as a practice for managing cultural heritage but this could also improve urban ecology. Water from the Bottini could be easily used for street washing, gardening, playgrounds watering and other uses. Through an emergy evaluation we demonstrated that this is desirable because the environmental impact of water in the Bottini is much lower than the water provided by the modern management system. The emergy 
per unit water are $1.38 \times 10^{10} \mathrm{seJ} / \mathrm{kg}$ and $3 \times 10^{9} \mathrm{seJ} / \mathrm{kg}$, respectively, but the emergy used in the ancient system, that is still efficient, is totally obtained by renewable inputs. Promoting a reuse of the ancient Bottini in Siena is probably a good opportunity not only for managing precious cultural heritage but also for improving urban ecology.

\section{References}

[1] Kucher M P. The Use of Water and its Regulation in Medieval Siena. Journal of Urban History, 31, 504-536, 2005.

[2] Bargagli Petrucci F. Le fonti di Siena e i loro acquedotti. Note storiche dalle origini fino al MDLV. Vol. I. Firenze, Olschki, 1905.

[3] Balestracci D, Vigni L \& Costantini A. La memoria dell'acqua. I Bottini di Siena. Protagon editori. Siena, Italia, 2006.

[4] Barone L, Calzolari V, Costantini A, LA DIANA, Santini R, Serrino G, Siena città dell'acqua - Bottini. Progetto C.E. Raphael, Siena, Italia, 2000.

[5] Baldi A M. Gli antichi Bottini Senesi. Tecnica di Idraulica Antica Supplemento 4, SIGEA, 2006.

[6] Becatti A, Ceccanti M, Vigni V. L'acqua dei Bottini: una risorsa da rivalutare. ARPAT News, 117, 2007.

[7] Amministrazione Provinciale di Siena. Relazione sullo Stato dell'Ambiente della Provincia di Siena 2008. MicroCosmos Onlus, Siena, 2009.

[8] Odum H T. Systems ecology. Wiley, New York, US, 1983.

[9] Odum H T. Environmental accounting: Emergy and Environmental Decision Making. Wiley \& Sons, New York, USA, 1996.

[10] Pulselli R M, Pulselli F M, Rustici M. The emergy accounting of the Province of Siena: towards a thermodynamic geography for regional studies. Journal of Environmental Management 86 342-353 2008.

[11] Pulselli R M, Simoncini E, Pulselli F M, Bastianoni S. Emergy analysis of building manufacturing, maintenance and use: em-building indices to evaluate housing sustainability. Energy and Buildings 39(5) 620-628 2007.

[12] Pulselli F M, Pulselli R M, Patrizi N, Marchettini N. Emergy evaluation of water management in the Florence area. (Ed.) Brown M T, Emergy Synthesis 5: Theory and Applications of the Emergy Methodology. University of Florida. Gainesville, FL 355-366 2009. 